\title{
Conceptualising strategic litigation
}

OÑATI SOCIO-LEGAL SERIES, FORTHCOMING

DOI LINK: HTTPS://DOI.ORG/10.35295/OSLS.IISL/0000-0000-0000-1226

RECEIVED 11 DECEMBER 2020, ACCEPTED 09 JUNE 2021, FIRST-ONLINE PUBLISHEd 30 SEPTEMBER

2021

\section{KRIS VAN DER PAS*}

\section{Abstract}

This article conceptualises the term "strategic litigation" in order to provide for a definition of it. Strategic litigation is a tool increasingly used in Europe by individuals and organisations to attain different objectives. Next to that, there is increasing academic attention for the topic. Nevertheless, the exact definition of "strategic litigation" remains unclear. Therefore, this article uses the research method of conceptualisation as well as a database research and additional literature to provide for a definition. It looks firstly at the background concept, involving the range of meanings associated with the term "strategic litigation", after which a systematised concept is formed. Thereby, use is made of the "necessary and sufficient conditions" (NSC) approach, to develop the conditions necessary and/or sufficient for a case to fit within the category of strategic litigation. Moreover, the external conceptual relations of the term are explored.

\section{Key words}

Strategic litigation; conceptualisation; definition; legal mobilisation; database research

\section{Resumen}

Este artículo conceptualiza el término "litigio estratégico" para proporcionar una definición. El litigio estratégico es un instrumento cada vez más usado en Europa por parte de personas y organizaciones para conseguir diversos objetivos, y hay un interés académico creciente por el tema. Sin embargo, la definición exacta de "litigio estratégico" sigue siendo poco clara. Por tanto, el artículo emplea el método de investigación de la conceptualización junto con una investigación de bases de datos y literatura adicional, y propone una definición. En primer lugar, se fija en el concepto de fondo, que incluye el abanico de significados relacionados con el término "litigio estratégico"; a continuación,

\footnotetext{
* PhD Candidate Radboud University, affiliated with the Centre for Migration law, the department of international and European law, and the Institute for Management Research. Postal address: Grotiusgebouw, Radboud University, Montessorilaan 10, 6525 HR Nijmegen. Email address: kris.vanderpas@ru.nl
} 
se forma un concepto sistemático. De este modo, se parte del enfoque de "condiciones necesarias y suficientes" (CNS) para desarrollar las condiciones necesarias y/o suficientes para que un caso encaje en la categoría de litigio estratégico. Por añadidura, se examinan las relaciones conceptuales externas del término.

\section{Palabras clave}

Litigio estratégico; conceptualización; definición; movilización jurídica; investigación de bases de datos 


\section{Table of contents}

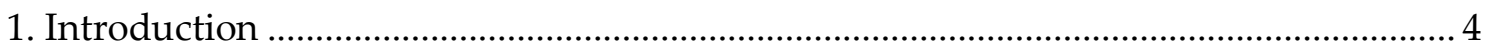

2. Background concept: Method and preliminary observations ......................................... 5

3. Systematised concept: Constitutive dimensions and definition.................................... 7

3.1. Strategy in two ways: The two main elements....................................................... 8

3.2. The sub-elements: Creating change .................................................................. 9

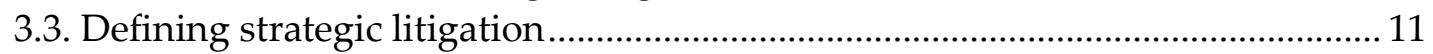

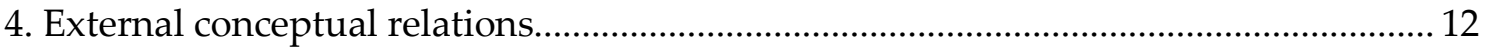

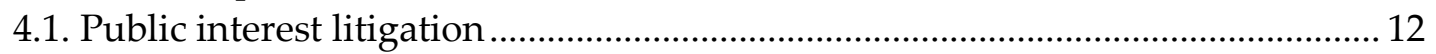

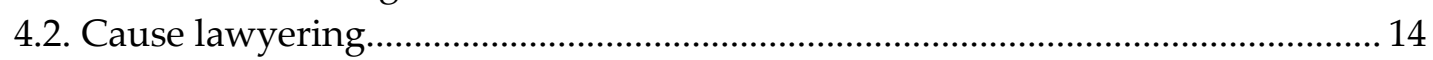

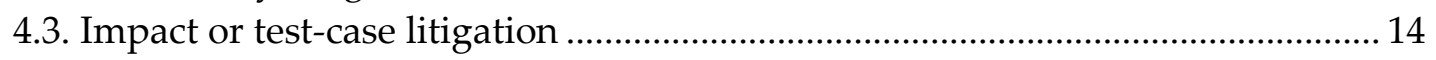

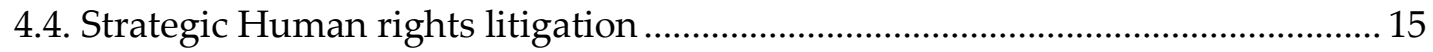

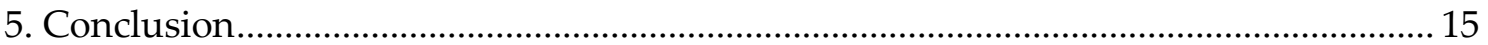

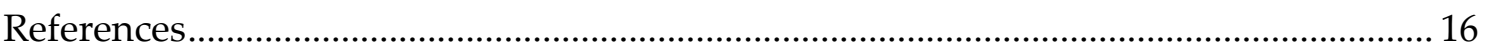

Annex: Tables with definitions/descriptions of "strategic litigation" .............................. 18 


\section{Introduction}

This article aims to clarify what constitutes the definition of strategic litigation. Strategic litigation, as part of the umbrella term "legal mobilisation", is a phenomenon and strategy that is increasingly used throughout Europe in various legal fields, such as environmental law and migration law. In this regard, there is also increasing attention in academic research for strategic litigation (Fuchs 2013, O'Neill 2015, Duffy 2018). Despite growing consideration for the topic, there is no single agreed-upon definition of the term strategic litigation (Ramsden and Gledhill 2019). Moreover, it is unclear what elements and conditions are part of the concept. Therefore, this article intends to provide clarity on what the term strategic litigation exactly entails. In the U.S. context, similar debates on the meaning of the U.S. counterpart of strategic litigation, public interest litigation, have been taking place for a longer period of time (Chen and Cummings 2013). The current article proceeds by conceptualising the term strategic litigation. Strategic litigation does not have an all-encompassing definition that can be found in legal dictionaries. Conceptualising a term is in fact providing for a definition (Goertz 2006 cited Robinson 1950). Furthermore, conceptualising strategic litigation here contributes to an ongoing academic debate on the definition of strategic litigation.

Use is made in this article of a variety of sources from the social sciences on conceptualisation, with which a method is put forward to conceptualise strategic litigation. Before delving into the conceptualisation of the term, two articles deserve attention here as they were the catalysts for writing this article. The first is an article by Ramsden and Gledhill (2019), in which they emphasised the need to define strategic litigation and in which they made an attempt at finding main indicia for strategic litigation. In their article, they explicitly called upon other academics to further develop a definition of the term strategic litigation. The second article is by Lehoucq and Taylor (2020), who conceptualised the term legal mobilisation. Legal mobilisation entails mobilising the law, often linked to social movements that use the law for political participation (Zemans 1983, Burstein 1991, McCann 2006). Legal mobilisation is understood as the situation "when a desire or want is translated into a demand as an assertion of one's rights" (Zemans 1983, p. 700). Strategic litigation, in that regard, flows from legal mobilisation, as litigation is one of the ways in which the law can be mobilised. Lehoucq and Taylor used the "necessary and sufficient conditions" (NSC) approach to conceptualise legal mobilisation. This approach is adopted here as well, although first a different method is used.

The first method adopted in this article uses the article on measurement validity by Adcock and Collier (2001). In their article, they refer to the use of two levels of a concept (Adcock and Collier 2001, p. 530). The first is the broadest level, encompassing the background concept. This background concept entails multiple meanings of a concept, gathered from various sources, which are commonly associated with the concept. After gathering these meanings, a systematised concept is formed. This consists of the constitutive dimensions of the background concept (Goertz 2006, p. 6). The systematised concept provides for a definition. The process of forming a systematised concept from a background concept is used here to conceptualise strategic litigation.

The constitutive dimensions of strategic litigation can be created by looking at the term in more detail. It consists of two words: litigation and strategic. Litigation is a term 
included in legal dictionaries. It entails essentially the process of engaging in a lawsuit. The second word, strategic, is harder to define. For example, in Black's Law Dictionary $\left(2019,11^{\text {th }}\right.$ ed.), the word is defined as follows: “[H]elping to achieve a plan, for example in business or politics". However, in academic literature on the term strategy (where the word strategic is derived from), no one agreed-upon definition can be found (de Wit 2017). Different approaches to and contexts of the term strategy can be found. The most relevant are incorporated in the current research, in order to define "strategic" in strategic litigation. In doing so, literature on the notion strategy is used.

Next to providing for a background concept and forming a systematised concept, use is made of the previously mentioned NSC approach. A concept is in this approach defined by giving it "the conditions necessary and sufficient for something to fit into the category" (Goertz 2006, p. 7). For strategic litigation, this means providing the conditions with which it can be determined whether a case (judicial process) fits within the concept strategic litigation. The necessary conditions have to be fulfilled in order for a case to be considered as strategic litigation. All necessary conditions need to be present. A sufficient condition, on the other hand, is a condition that, if fulfilled, always makes something part of the concept. Thus, in the present article, a sufficient condition would be a condition for which you need nothing else to classify a case as strategic litigation. The NSC approach can be contrasted with the family resemblance approach, which does not involve necessary conditions (Goertz 2006). It focuses on resemblance of conditions to a concept, and builds on the logic of sufficiency (Lehoucq and Taylor 2020, p. 175). This article uses the NSC approach, as the use of the family resemblance approach can lead to "conceptual stretching", meaning that the number of judicial cases that could fall within the concept of strategic litigation can expand greatly. This could render the use of this definition in further research practically unworkable. Thus, the purpose of the present article is to create a concept that is useful for further research by preventing conceptual stretching. On the other hand, this paper also aims to provide for a useful (working) definition for further research, that allows academics to use the concept for the purposes of their research. The reasoning behind this is that the notion strategic litigation is presently used in a variety of academic contributions without clarity as to what is exactly meant with the term. This practice could obstruct useful academic discussions on the concept.

\section{Background concept: Method and preliminary observations}

As stated above, in order to conceptualise strategic litigation, firstly an overview is to be made of the different meanings of strategic litigation forming the background concept. From this inventory of meanings, a systematised concept (and the constitutive elements) can be derived. To create an overview of meanings, a database research as well as a more specific research on NGO websites has been conducted. This has resulted in four extensive tables (see Annex). The first table consists of several definitions or descriptions of strategic litigation provided on the websites of twenty NGOs. The selection of NGOs is based on a Google search and research on NGOs that are known for their use of 
strategic litigation. ${ }^{1}$ The other three tables are based on database research, with each database represented in a different table. This specific research method was proposed by Ramsden and Gledhill (2019, p. 410), as they conducted a Google search of the term "strategic litigation" and analysed the first 100 outcomes. They proposed that academics use other research methods, such as database research, in order to add to the academic debate on the definition of strategic litigation.

This research has used three (legal) databases, namely Google Scholar, HeinOnline and Westlaw. They were used with the search term "strategic litigation". The first 20 hits that came up (which mainly included academic articles) were systemically indexed, including the definition or description of strategic litigation that was provided in the search result. 20 search results were included, because the total of 60 results overlapped largely among the three databases and search results after the first 20 referred to strategic litigation to a lesser extent. The 20 entries were sorted in each database based on "relevance". Many of the results included strategic litigation in the title of the article or mentioned strategic litigation multiple times. Because the topic strategic litigation made up a large part of the entries, they were most relevant to include in the research. Sorting the search results based on, for example, "most cited" could also lead to interesting results. Nevertheless, this included articles mentioning strategic litigation only once and probably for that reason often no description of the concept was provided. ${ }^{2}$ No claims are made here about the validity of the meanings provided by different authors when establishing the background concept (Adcock and Collier 2001, p. 532). Some preliminary comments on the tables are made below.

A few observations can be made regarding the type of literature that came up in the database research. Many of the authors from the database search write about strategic litigation in a specific context, for a specific type of cause. Examples include gender and sexuality, reproductive/women's rights, animal welfare, labour, and non-discrimination. More generally, some articles concern strategic litigation in the context of human rights, which is elaborated on later in this article (see section 4.4). Another group of articles pertains to the impact of strategic litigation or the consequences of using strategic litigation as a tool. Some entries are the odd ones out. One article talks about strategic litigation theory as a theory of political science, which did not come up anywhere else (table Google Scholar entry 8). Another article talks about a lawsuit in international humanitarian law, of which it is not explained why that was a case strategically litigated (table Google Scholar entry 10). One article is about using strategic litigation to get a business advantage (table HeinOnline entry 11). This seems to relate to three other entries, concerning a very specific type of strategic litigation, namely Strategic Lawsuits Against Public Participation (SLAPPs) (table Google Scholar entries 14, 17 and 18). Such lawsuits are conducted by businesses to drain resources of NGOs in order to obstruct

\footnotetext{
1 These last NGOs were for example mentioned in (news) articles, papers and books or came up in conversations with academic researchers, lawyers and NGO members. The table does definitely not provide for an exhaustive list of such NGOs, but a mere exemplary list.

2 For example, the most cited article of HeinOnline when using the search term "strategic litigation" mentioned strategic litigation only once; see Lemley and Weiser 2007. A definition or description of the concept was not provided.
} 
the work of these NGOs. This is a very specific phenomenon that is not addressed in detail in this article.

A second observation regarding the tables is that many results from the databases, amounting to almost a third of all results, do not provide for a clear definition or description of strategic litigation, or offer no definition or description at all. Some authors include "strategic litigation" in the title of their article and still do not clarify what strategic litigation entails. Moreover, what is surprising is that some NGOs that claim they use strategic litigation as part of their activities do not attempt to provide a definition or description of strategic litigation (table NGOs entries 2, 7, 8, 9, 15 and 16).

A final observation is that the entries that do include a definition or description of strategic litigation contain similar elements. This implies some form of consensus in academic literature and the practice of NGOs on what strategic litigation entails. This is not to say that many entries provide the same or a similar definition or description. The similar, or common, elements are not included in each entry and the way the elements are described is at times vastly different. These elements offer guidance to establish the systematised concept of strategic litigation and develop the necessary and/or sufficient conditions of the concept.

\section{Systematised concept: Constitutive dimensions and definition}

The different definitions and descriptions provided by the entries in the tables create the opportunity to distil a systematised concept. The two terms within the concept, strategic and litigation, need to be explored in more detail in order to do this. With regard to the term litigation, as indicated, it essentially concerns the process of engaging in a lawsuit. In legal dictionaries, several different definitions can be found, although they all come down to a similar description. Litigation means taking legal action in a court or other judicial mechanism. This is done with the intention of securing an outcome, mostly consisting of a judgment, although a case can also be settled. Moreover, it could be that the intention or threat of using litigation will result in a desired outcome. Litigation is undertaken by either an affected party itself or on behalf of an affected party. Thus, the initiators of (or participants in) the process of litigation can be the victim of a (legal) wrong, but they can also be an organisation that wants to aid these victims. As litigation (or the threat of litigation) is an essential aspect of strategic litigation, it consists of a necessary condition in light of the NSC approach.

This paragraph delves deeper into the adjective "strategic" that forms part of the concept of strategic litigation, because strategic (or strategy) is more difficult to grasp than litigation. Common elements that were found in the tables have been coded (see Annex). This has led to an overview of the specific common elements that are mentioned by authors when describing strategic litigation and the different ways in which they are described. The common elements have been researched in more detail, resulting in two main elements and further sub-elements as part of the word strategic and part of the systematised concept. A literature review has been carried out to elaborate on the meaning of the word "strategy". Below, the two main elements part of the word strategy are firstly explained combined with the literature review. These two main elements consist of different meanings of the term strategic. After that, a third common element will be explained in more detail. This common element forms a sub-element of one of 
the main elements. Thereafter, a graphic depiction of all elements, including the description of the word litigation, will be provided. Finally, on that basis the definition of strategic litigation is formulated.

\subsection{Strategy in two ways: The two main elements}

The first main element of the word strategic can be derived from one of the common elements found in the tables. This common element entails that in some entries, "strategic litigation" is used to describe specific choices made within litigation. The entries in the tables discuss different determinants or tactics that are used in court proceedings (table Google Scholar entry 16, table HeinOnline entry 2). Although this element is not mentioned in many entries, it is still relevant, because first of all, strategic litigation as a concept contains the term strategic which implies specific choices that are made. Secondly, two specific entries refer to strategic litigation as litigation used in a tactical or strategic manner (table NGOs entry 1, table Google Scholar entry 13). In doing so, certain choices need to be made within litigation.

This common element refers to the cognitive process of strategy (de Wit 2017, p. 4), i.e. the decision-making process. This means that strategy in this regard means "ploy" (or multitude of ploys), a specific move (Mintzberg 1987). Within a process, choices are made based on the circumstances. Thus, based on analysis and logic (or imagination and judgment), the "strategists" (the litigants) make choices in the (dynamic) process of litigation. For example, this could entail choosing a specific international court to increase chances of a positive outcome of a case. It could also entail choosing not to bring an argument in a case that will likely not get the desired result, but instead using it in a different case. Thus, the first main element of the term strategic refers to strategy as a multitude of ploys or choices that are made within the process of litigation.

The second main element as part of strategic relates to litigation being used as a strategy within a range of other strategies. For example, the website of the Global Legal Action Network (GLAN) states: "Our strategies are diverse and include litigation". In some articles, strategic litigation is described as a "deliberate strategy" (table Westlaw entry 2), "part of a strategy" (table Westlaw entry 10), or as a "political strategy" (table Google Scholar entry 11). In other articles, it is not explicitly mentioned, but it is implied that litigation is used as a strategy. Some authors do not refer to the word "strategy", although they mention that litigation is used as a "tool". Examples include references to "advocacy tool" (table Google Scholar entry 3), "a combination of legal tools and traditional advocacy techniques" (table Google Scholar entry 6), and "litigation as a viable strategic tool" (table HeinOnline entry 8). Ramsden and Gledhill (2019, p. 423) find a similar connection in their research. Both strategy and tool refer to the same thing: namely that litigation is an option in a range of other "tools" or "strategies" and that it is specifically chosen. Strategy in this context refers here to a means to reach an overarching objective, or multiple objectives (de Wit 2017). It is used to describe an intended course of action (Mintzberg 1987). Therefore, the litigants have specifically chosen litigation to achieve their objectives. This is different from the first common element described above, where strategy refers to specific choices made within the litigation process, as opposed to litigation as an overarching strategy. 
Thus, "strategic" in the concept strategic litigation has a twofold meaning. First of all, it refers to the cognitive process within litigation, where choices are made by the litigants. The second meaning of strategic is that litigation is used as a means to reach an overarching objective. This has consequences for the description of the term litigation as well. There can be situations where the intention of using litigation is a strategy. The intention of taking legal action is the means to reach an objective. Therefore, the term litigation in the concept strategic litigation entails also the intention of taking legal action.

The question that is subsequently relevant is: What is the relation between the two dimensions as part of strategic/strategy? For this, we return to the NSC approach described above. Both dimensions as part of "strategic" can be described as necessary conditions, as a case needs to fulfil both conditions to be considered strategic litigation. Firstly, the cognitive process within litigation, thus the strategic choices made within the litigation process, is required to be present. Secondly, litigation must be used as a means to reach an overarching objective or objectives. This is also part of the core of the concept strategic litigation, as a case cannot be classified as strategic litigation if this condition is not fulfilled. This second main element refers to an overarching objective or objectives: what these objectives are is elaborated on below, in the sub-element derived from one of the common elements found in the tables.

\subsection{The sub-elements: Creating change}

The element of using litigation as a means (intended course of action) to achieve certain objectives requires a further exploration of what these objectives are. The possible objectives can be derived from many entries that include a description of these goals in various ways. Most descriptions refer to something similar: namely that strategic litigation is intended to create some form of change. Some of the entries in the tables talk about creating "broader change" (table NGOs entry 11) or "broader social/legal/policy change" (table NGOs entry 14, table HeinOnline entry 20). Some speak of "broad impact" (table Google Scholar entry 3) or "wider impact" (table NGOs entry 4). Especially the terms "broader change" and "wider impact" can be confusing. A question that may arise is: broader/wider than what?

Other descriptions give clarity in that regard. Broad(er) change or impact means that the change that is envisioned goes beyond the individual interest or individual case. Thus, strategic litigation is about creating change "beyond the case concerned" (table Google Scholar entry 5) or (more elaborately) "broader than traditional client-focused legal services" (table Google Scholar entry 6). It can be useful in this regard to talk about the negative pole of the concept, i.e. explicitly contrasting the concept with the other end of the spectrum (Goertz 2006, pp. 31-32). For strategic litigation, this means contrasting it with "regular" litigation. ${ }^{3}$ In "regular" litigation, the aim of the litigants is to win the case to advance their own interest. Lawyers representing their clients want to win a case in order to advance their clients' interest. In strategic litigation, the objectives that the litigators want to attain go beyond the individual interest or the individual case. Thus, either the aim is to create change beyond the individual interest, for example when

\footnotetext{
${ }^{3}$ Regular litigation refers here to the use of judicial mechanisms by parties representing their own interests, or a lawyer representing only their clients' interest.
} 
winning one case affects a large group of people, such as a climate change case. Next to that, the aim can be to create change beyond the individual case, meaning that multiple (similar) cases are affected by one specific case. The aim is to advance different interests and effect change.

What type of change does strategic litigation want to create? The answer to this question varies greatly and examples can be found in the different descriptions in the tables. Some entries try to describe in detail the different types of changes that strategic litigation wants to create, by giving specific examples (table HeinOnline entry 9) or listing a number of fields ("legislation, policies, practices, or influencing public opinion and awareness", table HeinOnline entry 6). Other examples that can be added are setting precedents, pointing to gaps in legal protection, or solving politically sensitive issues. Some descriptions remain more vague and describe in broad terms the type of change, such as "law and policy reform" (table Westlaw entry 4) or "social change" (table Westlaw entry 10).

Because of these differences, in order to conceptualise strategic litigation for this research, use will be made of a broad description. This description can be classified as a necessary condition. Therefore, a sub-element of the necessary condition that litigation is used as a means to reach certain objective is the necessary sub-condition that strategic litigation wants to realise change that goes beyond the individual interest or individual case. This way, all different intended changes that strategic litigators want to make are included. The different types of change are included as non-exhaustive examples, and therefore these are neither necessary nor sufficient conditions.

The question that remains here is whether a case has to be started in a strategic manner, or can also become strategic over the course of the proceedings. For the purpose of this article, it is not relevant whether a case is started as a strategic litigation case or whether a case "becomes" strategic litigation. The main element that litigation is used in a strategic manner does not exclude this. An example would be a case started in a lower court, which is discovered as a potentially influential case on appeal. This case could become "strategic", as now this case is used (by an NGO, for example) as a strategy to obtain a certain objective, for example legal change for a substantial group of people. This is also supported by the description in the article of Koppelman, who describes cases that become strategic as another model of strategic litigation (table Google Scholar entry 2). Baumgärtel argues that cases can also become strategic after the judgment has been issued (Baumgärtel 2019). Such cases are not part of the concept of strategic litigation as defined in this article: a case cannot become strategic after the judgment has been delivered. The reason why such cases are not included in the concept of strategic litigation in this research has to do with the main element and necessary condition of an intended course of action to achieve objectives and the sub-element and necessary subcondition of realising change. Realising change was not part of the intended course of action when the case was being litigated, and therefore the case is not part of strategic litigation. Nevertheless, a case can always have more impact than was foreseen before, during or after the trial. 


\subsection{Defining strategic litigation}

The aforementioned can be put in a graphical presentation, depicting the different elements part of the concept strategic litigation.

FIGURE 1

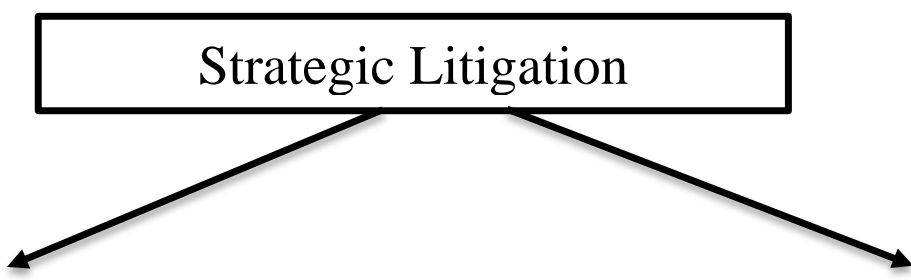

*Litigation: (intention of) legal action through a judicial mechanism in order to secure an outcome (mostly a judgment), either by an affected party or on behalf of an affected party. It is the process of engaging in a lawsuit.
Legal change (e.g. setting precedents).

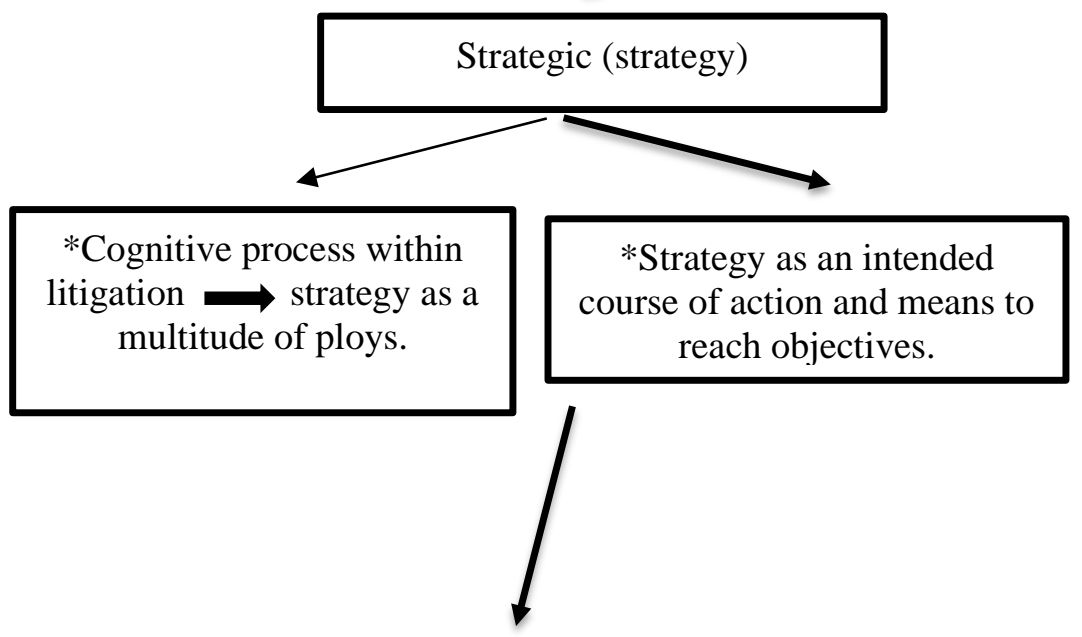

*These objectives consist of creating change/impact beyond the individual interest or individual case concerned.

Figure 1: Elements of Strategic Litigation.

The necessary conditions are depicted with an asterisk $\left({ }^{*}\right)$. All these conditions need to be present to classify a case as strategic litigation. The types of change that are included at the bottom of the figure are neither necessary nor sufficient conditions, but they are mere examples of the types of change. Therefore, no sufficient conditions are part of the concept strategic litigation.

To sum up, the elements that are derived from the descriptions provided in the tables as well as academic literature result in the following definition of the systematised concept:

Strategic litigation is (the intention of) legal action through a judicial mechanism in order to secure an outcome, either by an affected party or on behalf of an affected party. The legal action is used as a means to reach objectives, which consist of creating change (e.g. legal, political, social) beyond the individual case or individual interest. To 
effectuate this change, certain tactical (strategic) choices based on the circumstances are made by the litigants in the process.

\section{External conceptual relations}

Adcock and Collier (2001, p. 532) warn scholars for several traps that can occur when establishing a systematised concept. One of these traps is based on psychometrics literature, as Shepard has stated: "The conceptual framework that lays out our understanding of a construct includes both an internal model of interrelated dimensions or subdomains of a construct and an external model depicting its relationship to other constructs" (Shepard 1993, p. 417). Next to establishing the interrelated dimensions of a concept, which has been done above, a concept should be contrasted with external concepts related to it, according to Adcock and Collier. Therefore, this article devotes attention to four terms used to describe a similar phenomenon to strategic litigation and the article deals with the relation of those terms with the concept of strategic litigation. This approach helps to highlight the specific aspects of the concept of strategic litigation compared to the other terms. These terms include public interest litigation, cause lawyering, impact litigation and test-case litigation, and strategic human rights litigation (Ramsden and Gledhill 2019). These terms also pop up in some of the entries in the tables. The Helsinki Foundation for Human Rights describes strategic litigation as "conducting court cases of public interest" (table NGOs entry 20), Fuchs refers in her description to "test cases" (table Google Scholar entry 4), and LeDuc states that strategic litigation is also referred to as "impact litigation" (table HeinOnline entry 9). This paragraph deals with the different concepts and their relation to strategic litigation in consecutive order.

\subsection{Public interest litigation}

Public interest litigation is the term most used in academic literature, especially literature originating from the United States. The term first coined in the US and ever since that, the meaning of the term has been open to debate (Chen and Cummings 2013). Chen and Cummings, US professors specialising in (among others) public interest law, spend the entire first chapter of their book defining the concept of "public interest lawyering". On the first page of this chapter, they warn their readers that no ideal definition can be found ("no definition is unassailable") (Chen and Cummings 2013, p. 3). Despite this ongoing debate, the term has exported from the United States and is used in literature around the globe (Cummings and Trubek 2008). In Europe, there appears to be a regional preference for the concept strategic litigation (Ramsden and Gledhill 2019). This could be the case because public interest litigation is a term defined by different factors, which depend on who uses them, making the term harder to grasp.

Chen and Cummings (2013) try to clarify the relevant factors within the debate when discussing the meaning of public interest litigation/lawyering. The discussion on the meaning of the concept centres on defining what qualifies as a "public interest". According to Chen and Cummings (2013, p. 5), public interest law is "a terrain upon which competing social interests do battle in order to define the very meaning of a just society". This shows that the definitional debate surrounding public interest law is different from strategic litigation: the competing social interests are irrelevant for 
strategic litigation, as it is not relevant what specific type of change one wants to achieve. The necessary condition of the concept is that litigation is used as a means to attain this.

Defining public interest comes with a debate on what it takes for a case to be in the public interest (or for the public good). Therefore, the debate (at least in the United States) is also politically framed (Southworth 2005, Chen and Cummings 2013, Ramsden and Gledhill 2019). For example, early definitions of public interest law focused on representation of underrepresented groups; conservative movements did not agree with this definition, as to their minds it focused too much on equity. Moreover, it is hard to define what an underrepresented group is. Besides that, if an underrepresented group is represented via public interest litigation, do they still qualify as underrepresented? This (political) debate has not taken place with regard to the concept of strategic litigation. In the Indian tradition of public interest litigation, the public interest is defined as a legal category of cases in which a person or group of persons has been legally wronged and is unable to approach a court, and therefore another person (of the public) can address the court about that legal wrong (Deva 2009). This consists of litigation on behalf of (a group of) underrepresented people and amounts to a legal category of cases. Public interest is in that regard not politically framed. This type of litigation is reflected in the concept strategic litigation in the element "on behalf of an affected party" and the necessary condition of change beyond the individual case or interest.

Several criteria have been identified by Chen and Cummings that are relevant in defining public interest (law) in the US. The previously mentioned criteria of underrepresented groups (market-based representation) or other clients that do not, or only barely have access to courts (access-orientation), are both factors possibly pointing to a public interest (Chen and Cummings 2013, pp. 12-14). Moreover, helping clients that are not represented in political spaces with going to court is a relevant factor (this can be called the policy dimension) (Cummings 2012). The access-orientation and policy criteria are interesting when comparing these with the types of change listed in the figure on the concept of strategic litigation. The access dimension is related to the legal change that strategic litigation possibly wants to create: if groups are not represented in court, setting a precedent that might help larger groups of people. This is a form of strategic litigation that is also part of public interest litigation using access-orientation as a defining factor. The policy dimension is reflected in the possibility of wanting to achieve policy change with strategic litigation.

A second set of criteria to define public interest litigation is related to the motivation of individuals when pursuing public interest litigation. This motivation can be related to altruism, political and moral commitment, or changing the status quo (Chen and Cummings 2013, pp. 22-29). These are generally also linked to the concept of cause lawyering, which is discussed below. Although this set of criteria is not reflected in the elements of the concept of strategic litigation in this research, changing the status quo is mentioned in one of the entries in the tables (table Google Scholar entry 19).

The third set of criteria is institutional; they concern the practice site and legal skills (although the latter are considered less appropriate by the authors) (Chen and Cummings 2013, pp. 30-32). As for the practice site, not-for-profits are generally seen as suitable for practicing public interest litigation. Nevertheless, in the concept of strategic litigation for this research, it is not necessary that a not-for-profit firm (or lawyer) is 
conducting the litigation. An example is the Dutch law firm Prakken d'Oliveira. This is a private firm that takes on cases that could qualify as strategic litigation cases. ${ }^{4}$ The practice site is still an indicator: organisations wanting to advance rights of groups of people will generally litigate cases that advance these rights beyond an individual (also because this is most effective).

In sum, some criteria for defining public interest litigation mentioned by Chen and Cummings can be related to the concept of strategic litigation in this research. These criteria are reflected in either a necessary condition or an example of the type of change that is the objective of strategic litigation. Nevertheless, not all criteria mentioned are reflected in the definition of strategic litigation provided in this article.

\subsection{Cause lawyering}

Because of the previously mentioned debate on the term public interest litigation, another term has been introduced in academic literature, namely cause lawyering (Scheingold and Sarat 2004). Ramsden and Gledhill (2019, p. 418) even state that the other terms (public interest litigation, impact litigation etc.) fall within the "cause lawyering lexicon" (or lawyering for change lexicon). The emphasis in this term lies, as can be derived from it, on lawyers. The previously mentioned criteria of motivation of individuals (for defining public interest litigation) is applicable to define this concept. Leading academics on cause lawyering Scheingold and Sarat (2004, p. 3) define it as follows: "at its core, cause lawyering is about using legal skills to pursue ends and ideals that transcend client service - be those ideals social, cultural, political, economic, or, indeed, legal. (...) [P] olitical or moral commitment [is] an essential and distinguishing feature of cause lawyering." There is a similarity in this definition to the concept of strategic litigation discussed above, namely the types of ideals that are mentioned. Nevertheless, the focus of the definition by Scheingold and Sarat is on the subjective motivation of an individual (lawyer). Political or moral commitment is not relevant in the definition of strategic litigation provided above.

\subsection{Impact or test-case litigation}

Impact litigation and/or test-case litigation is referred to in some academic literature to describe strategic (or public interest) litigation (table Westlaw entry 2). As for impact litigation, the relation with the concept of strategic litigation is rather obvious; the necessary condition of creating change correlates with impact litigation. Nevertheless, in the necessary condition described for strategic litigation it is added that the change goes beyond the individual interest or individual case.

Test-case litigation, or test cases in general, has also been referred to when describing strategic litigation in the entries in the tables. This term seems to imply a random effect: bringing cases to test a certain argument or test a certain court. However, test cases can also be carefully crafted in order to see how certain legal issues are addressed by courts. Thus, a specific strategy can be part of a test case. When comparing this to the concept of strategic litigation, it can be said that bringing a test case is one way of using strategic

\footnotetext{
${ }^{4}$ Examples include a case about the boat Sea-Watch retrieving migrants from the Mediterranean Sea (Prakken d'Oliveira 2019b) and a case about retrieving Dutch women and children from Syria (Prakken d'Oliveira 2019a).
} 
litigation. Both conditions related to the word "strategy" in strategic litigation can be reflected in a test case. A test case can have an overarching objective to create change (beyond the individual interest/case), but also a test case can be specifically designed, meaning that there is a specific strategy (multitude of ploys) used in the test case.

\subsection{Strategic human rights litigation}

In many of the entries in the tables, a reference can be found to human rights. They either describe strategic litigation as a phenomenon using/advancing human rights, or they describe strategic litigation as strategic human rights litigation. Ramsden and Gledhill (2019, p. 408) note in their article that strategic litigation and strategic human rights litigation are sometimes used interchangeably, which implies a link between strategic litigation and human rights. Duffy (2018) compares strategic human rights litigation to public interest litigation and impact litigation. The focus in her definition is mostly on impact beyond the individual and the link with human rights is not explored further. ${ }^{5}$ Her book explicitly leaves out a further discussion of the term, as the focus is on the impact of strategic human rights litigation. When looking at the concept of strategic litigation, the link to human rights can be inferred from the fact that change is intended beyond the individual interest. As human rights concern every individual, cases using human rights can more easily be classified as strategic litigation.

\section{Conclusion}

This article has provided for a definition of the term "strategic litigation" by conceptualising it. The importance of defining strategic litigation lies in the fact that it is a tool increasingly used throughout Europe and related to that is increasing academic attention for it. This article has firstly explored the background concept to develop the constitutive dimensions and systematized concept of strategic litigation, focusing on the word strategy. The article has gathered various meanings of the term strategic litigation through a literature review and database research to form the background concept. Afterwards, the NSC approach has been used to create a systematised concept, focusing on the two words "strategic" and "litigation". This definition contains several necessary conditions, namely that strategic litigation consists of (the intention of) legal action through a judicial mechanism in order to secure an outcome, either by an affected party or on behalf of an affected party and that litigation is used as a means to reach certain objectives. These objectives consist of the necessary condition of creating change beyond the individual case or individual interest. This change can consist of legal change, political change and/or social change, which are neither necessary nor sufficient conditions, i.e. they are not elements needed in order for a case to be considered as falling within the category of strategic litigation. A final necessary condition is that certain choices (or ploys) are made within the process of strategic litigation to create the change beyond the individual case or individual interest.

Next to providing for a definition, the external conceptual relations of strategic litigation have been discussed. Several related concepts, such as public interest litigation, cause lawyering, impact/test-case litigation and strategic human rights litigation describe a

\footnotetext{
${ }^{5}$ Given the content of the book, it can be assumed that her focus is on human rights bodies where cases have been litigated.
} 
similar phenomenon to strategic litigation. Therefore, this article has discussed what these concepts entail and how they relate to the concept of strategic litigation. It is rather difficult to define public interest litigation, despite it being the term most used in academic literature. This has to do with the fact that it is hard to define what a "public interest" entails. Criteria to define a public interest concern whether a group is underrepresented, based on political representation or access to justice. Other criteria defining public interest relate to individual motivation, which is similar to the core of the concept of cause lawyering. For defining this term, it is important what the motivation (namely political or moral commitment) of the individual lawyer is. This is not relevant for the concept of strategic litigation. The meaning of impact litigation is more similar to strategic litigation, as it relates to creating change. As for test-case litigation, such cases can be carefully crafted and can be part of the concept of strategic litigation. Lastly, strategic human rights litigation refers to an essential link with human rights, which could be part of strategic litigation but is not necessary.

\section{References}

Adcock, A., and Collier, D., 2001. Measurement Validity: A Shared Standard for Qualitative and Quantitative Research. American Political Science Review, 95(3), 529-546.

Baumgärtel, M., 2019. Demanding Rights: Europe's Supranational Courts and the Dilemma of Migrant Vulnerability. Cambridge University Press.

Burstein, P., 1991. Legal Mobilization as a Social Movement Tactic: The Struggle for Equal Employment Opportunity. American Journal of Sociology, 96(5), 1201-1225.

Chen, A., and Cummings, S., 2013. Public Interest Lawyering: A Contemporary Perspective. New York: Aspen.

Cummings, S., 2012. The Pursuit of Legal Rights - And Beyond. UCLA Law Review [online], 59, 506-549. Available from: https://www.uclalawreview.org/pdf/59-32.pdf [Access 22 July 2021].

Cummings, S., and Trubek, L., 2008. Globalizing Public Interest Law. UCLA Journal of International Law and Foreign Affairs [online], 13, 1-53. Available from: https://doi.org/10.2139/ssrn.1338304 [Access 22 July 2021].

de Wit, B., 2017. Strategy: An International Perspective. $6^{\text {th }}$ ed. Andover: Cengage Learning EMEA.

Deva, S., 2009. Public interest litigation in India: a critical review. Civil Justice Quarterly [online], 28(1), 19-40. Available from: https://ssrn.com/abstract=1424236 [Access 22 July 2021].

Duffy, H., 2018. Strategic Human Rights Litigation. Oxford: Hart.

Fuchs, G., 2013. Strategic Litigation for Gender Equality in the Workplace and Legal Opportunity Structures in Four European Countries. Canadian Journal of Law and Society [online], 28(2), 189-208. Available from: https://doi.org/10.1017/cls.2013.21 [Access 22 July 2021].

Goertz, G., 2006. Social Science Concepts: A User's Guide. Princeton University Press. 
Lehoucq, E., and Taylor, W.K., 2020. Conceptualizing Legal Mobilization: How Should We Understand the Deployment of Legal Strategies? Law $\mathcal{E}$ Social Inquiry [online], 45(1), 166. Available from: https://doi.org/10.1017/lsi.2019.59 [Access 22 July 2021].

Lemley, M., and Weiser, P., 2007. Should Property or Liability Rules Govern Information? Texas Law Review [online], 85(4). Available from:

https://scholar.law.colorado.edu/cgi/viewcontent.cgi? article=1346\&context=article s [Access 22 July 2021].

McCann, M., ed., 2006. Law and Social Movements. Aldershot: Ashgate.

Mintzberg, H., 1987. The Strategy Concept I: Five Ps for Strategy. California Management Review, 30(1), 11-24.

O'Neill, A., 2015. Strategic litigation before the European Courts. ERA Forum, 16(4), 495-508.

Prakken d'Oliveira, 2019a. Court of Appeal: The Dutch State is not obliged to actively help repatriate Dutch children and mothers from Syria. Prakken d'Oliveira [online], 6 December. Available from:

https://www.prakkendoliveira.nl/en/news/2019/court-of-appeal-the-dutch-stateis-not-obliged-to-actively-help-repatriate-dutch-children-and-mothers-from-syria [Access 24 August 2021].

Prakken d'Oliveira, 2019b. Sea-Watch also wins appeal against the Dutch State. Prakken d'Oliveira [online], 1 August. Available from:

https://www.prakkendoliveira.nl/en/news/2019/sea-watch-also-wins-appealagainst-the-dutch-state [Access 24 August 2021].

Pring, G., 1989. SLAPPs: Strategic Lawsuits against Public Participation. Pace Environmental Law Review [online], 7(1). Available from: https://digitalcommons.pace.edu/pelr/vol7/iss1/11 [Access 22 July 2021].

Ramsden, M., and Gledhill, K., 2019. Defining Strategic Litigation. Civil Justice Quarterly, 4, 407-426.

Scheingold, S., and Sarat, A., 2004. Something to Believe In: Politics, Professionalism, and Cause Lawyering. Redwood City: Stanford University Press.

Shepard, L.A., 1993. Evaluating Test Validity. In: L. Darling-Hammon, ed., Review of Research in Education. Washington, DC: AERA, 405-450.

Southworth, A., 2005. Conservative Lawyers and the Contest over the Meaning of Public Interest Law. UCLA Law Review [online], 52(4), 1223-1278. Available from: https://www.uclalawreview.org/wpcontent/uploads/2019/09/30 52UCLALRev12232004-2005.pdf [Access 22 July 2021].

Zemans, F., 1983. Legal Mobilization: The Neglected Role of the Law in the Political System. The American Political Science Review, 77(3), 690-703. 


\section{Annex: Tables with definitions/descriptions of "strategic litigation"}

\section{Color index}

Red: No definition

Green: Litigation as strategy

Blue: strategies/strategic choices within litigation

Purple: Broader change (legal, policy, social, political)

\section{Table of organizations (20)}

\begin{tabular}{|c|c|}
\hline Organization & Definition of Strategic Litigation (if provided) \\
\hline $\begin{array}{l}\text { 1) PILP-NJCM } \\
\text { https://pilpnjcm.nl/ }\end{array}$ & $\begin{array}{l}\text { Strategic litigation is the use of legal procedure in a } \\
\text { strategic way to bring about social, political or legal } \\
\text { changes. It can give a voice to individuals, protect } \\
\text { vulnerable minorities, and provide access to justice for those } \\
\text { whose rights are at stake. }\end{array}$ \\
\hline $\begin{array}{l}\text { 2) UNHCR } \\
\text { https://www.unhcr.org/ }\end{array}$ & $\begin{array}{l}\text { No definition is provided. Strategic litigation } \\
\text { mentioned as part of their work in: } \\
\text { https://www.unhcr.org/priorities-and-areas-of-work- } \\
\text { in-europe.html } \\
\text { https://www.unhcr.org/ngo-consultations/ngo- } \\
\text { consultations-2014/Friday-20-June-Side-meeting-on- } \\
\text { Strategic-litigation-and-international-refugee- } \\
\text { protection.pdf }\end{array}$ \\
\hline $\begin{array}{l}\text { 3) Vluchtelingenwerk (Dutch Council } \\
\text { for Refugees) } \\
\text { https://www.vluchtelingenwerk.nl/wat- } \\
\text { wij-doen/successen-voor-het- } \\
\text { programma-strategisch-procederen }\end{array}$ & $\begin{array}{l}\text { "The Committee (Strategic Litigation) chooses important, } \\
\text { principal cases that can have consequences for larger groups } \\
\text { of refugees in similar situations" }\end{array}$ \\
\hline $\begin{array}{l}\text { 4) The Aire Centre } \\
\text { https://www.airecentre.org/litigation1 }\end{array}$ & $\begin{array}{l}\text { "Where we identify critical human rights violations or gaps } \\
\text { in policy or law which affect individuals in Europe, we step } \\
\text { in and pursue cases with strategic potential. Such cases have } \\
\text { had a wider impact on a national and international level, } \\
\text { protecting the rights of vulnerable people including asylum- } \\
\text { seekers, people who are homeless, victims of trafficking and } \\
\text { survivors of domestic violence, to name a few." }\end{array}$ \\
\hline $\begin{array}{l}\text { 5) GLAN } \\
\text { https://www.glanlaw.org/what-we-do }\end{array}$ & $\begin{array}{l}\text { "GLAN's goal is to promote social change through strategic } \\
\text { legal action. We seek to use the law in new and innovative } \\
\text { ways to bring about legal, political or social impact. Our } \\
\text { strategies are diverse and include litigation in foreign and } \\
\text { international courts. We seek more than success in a } \\
\text { courtroom and our work includes legal actions before } \\
\text { administrative bodies and the dissemination oflegal analyses. } \\
\text { We work with individuals and communities resisting } \\
\text { injustice, empowering and amplifying their voices, in order } \\
\text { to challenge powerful actors involved in human rights } \\
\text { violations." }\end{array}$ \\
\hline
\end{tabular}


6) ECCHR

https://www.ecchr.eu/en/glossary/strateg ic-litigation/

https://www.icj.org/wpcontent/uploads/2016/08/ICJ-StrategicPlan-2016-2020.pdf

8) ASGI

http://www.asgi.it/progetti/out-of-limboenglish-version/

9) HIAS

https://www.hias.org/where/greece

10) TRIAL International

https://trialinternational.org/topicspost/strategic-litigation/

11) Children's Rights International

Network

(CRIN)

https://archive.crin.org/en/guides/legal/g uide-strategic-litigation/what-strategiclitigation.html

12) Validity

https:/validity.ngo/what-we-do/

13) Open Society Justice Initiative (report on strategic litigation)

https://www.justiceinitiative.org/upload s/fd7809e2-bd2b-4f5b-964f522c7c70e747/strategic-litigationimpacts-insights-20181023.pdf

14) ILGA-Europe

https://www.ilga-europe.org/what-wedo/our-strategic-litigation-work
"Strategic litigation aims to bring about broad societal changes beyond the scope of the individual case at hand. It aims to use legal means to tackle injustices that have not been adequately addressed in law or politics. It gives a platform for people affected by rights violations to be seen and heard, triggers discussion of these violations, and highlights weaknesses and gaps in the law. Successful strategic litigation brings about lasting political, economic or social changes and develops the existing law. Public outreach materials accompanying the case can help to explain the context of the proceedings. This increases the progressive and precedent-setting impact of the legal action."

No definition is provided. Strategic litigation mentioned as one of their strategies in the Strategic Plan 2016-2020

No definition is provided. On the English version of one of their projects, strategic litigation is mentioned as part of their work several times.

No definition is provided. Strategic litigation mentioned as part of their work.

"[Strategic litigation is] the identification and pursuit of legal cases as part of a strategy to promote human rights. It focuses on an individual case in order to bring about broader social change.

"[Strategic litigation] involves selecting and bringing a case to the courtroom with the goals of creating broader changes in society"

"[Strategic litigation is] taking a small number of individual cases to national, regional and international courts, Validity is a global leader in pushing for legal validation of the human rights of people with mental disabilities. Each case seeks to improve the lives of our clients and many other people who suffer similar human rights violation."

"For the purposes of this essay, the working definition of "strategic human rights litigation" is legal action in a court that is consciously aimed at achieving rights-related changes in law, policy, practice, and/or public awareness above and beyond relief for the named plaintiff(s)."

"Strategic litigation is the use of court cases as part of a strategy to achieve broader legal and social change. Strategic cases may be settled in the national courts, or, failing that, go to regional or international courts." 


\section{5) Equal Rights Trust \\ https://www.equalrightstrust.org/ert stra tegic litigation/index.htm}

16) ESCR (Economic Social and Cultural No definition is provided. Right)-Net

https://www.escr-

net.org/strategiclitigation

17) Society for Civil Rights (Gesellschaft für Freiheitsrechte, GFF)

https://freiheitsrechte.org/english/

8) The Initiative for Strategic Litigation in Africa

https://www.the-isla.org/

19) European Prison Litigation Network https://www.prisonlitigation.org/whowe are/?lang=en

20) Helsinki Foundation for Human Rights

http://www.hfhr.pl/en/hfhrs-guide-onstrategic-litigation-before-cjeu/
No definition is provided.

Taking these factors into account, GFF strategically selects its cases, plaintiffs and partners and supports them through legal expertise and active, information oriented campaigning. This approach guarantees that the case not only addresses isolated legal issues, but that it has a sustainable effect for human and civil rights both at the legal and at the societal level.

[...] strategic litigation is an immensely strong tool for social change because it helps to reframe the understanding of entitlements before the law and it challenges the legal discourse on women's rights and sexual rights. ISLA stands for the proposition that investment in local institutions and individuals is key to maximizing the impact of strategic litigation. ISLA seeks to use the rule of law and African domestic and regional courts to advance women's human rights and sexual rights.

No definition is provided.

Strategic litigation involves conducting court cases of public interest that aim at changing laws or practices that violate rights or freedoms of an individual, implementing a specific international or constitutional standard, engaging in advocacy of specific and serious problems to the general public and authorities and raising public awareness. 


\section{Table of search engine Google Scholar ${ }^{6}$}

\begin{tabular}{|c|c|c|}
\hline \multicolumn{2}{|c|}{ Search Result } & $\begin{array}{l}\text { Definition/description of Strategic Litigation (if } \\
\text { provided) }\end{array}$ \\
\hline 1) & $\begin{array}{l}\text { Fuchs, G., 2013. Strategic } \\
\text { Litigation for Gender Equality } \\
\text { in the Workplace and Legal } \\
\text { Opportunity Structures in Four } \\
\text { European Countries. Canadian } \\
\text { Journal of Law E Society, 28(2), } \\
\text { 189-208. }\end{array}$ & $\begin{array}{l}\text { "A central form of legal mobilization is litigation in } \\
\text { court, most often pursued with the strategic goal of } \\
\text { eliciting a favorable judgment to support demands and } \\
\text { arguments for legal change. Social movement } \\
\text { organizations or groups launch or support test cases in } \\
\text { court in order to promote legal and social change, } \\
\text { endeavoring to change law and policies, to ensure that } \\
\text { laws are properly interpreted and enforced, or to } \\
\text { identify gaps in the existing law. Rulings can also } \\
\text { directly alter practices, or they can be used to press for } \\
\text { policy changes." }\end{array}$ \\
\hline 2) & $\begin{array}{l}\text { Koppelman, A., 2008. The } \\
\text { Limits of Strategic Litigation. } \\
\text { Law E Sexuality: A Review of } \\
\text { Lesbian, Gay, Bisexual and } \\
\text { Transgender Legal Issues, 17(1), } \\
\text { 1-6. }\end{array}$ & $\begin{array}{l}\text { "In this model, gay rights organizations try to figure } \\
\text { out which courts are most likely to be receptive to their } \\
\text { claims, then recruit plaintiffs to challenge the laws on } \\
\text { the books and file suit. We think, then we act. The } \\
\text { whole undertaking is centrally planned in advance of } \\
\text { any legal activity. (...) } \\
\text { There is, however, another model that will be } \\
\text { increasingly relevant. That is the situation in which } \\
\text { parties who had no interest whatsoever in being public } \\
\text { interest plaintiffs find themselves unexpectedly trapped } \\
\text { in an evil legal system that threatens to treat them in a } \\
\text { viciously arbitrary and unfair way. The public interest } \\
\text { organization necessarily comes into the litigation late, } \\
\text { if at all. Instead of planning the litigation, the public } \\
\text { interest organization is as surprised as the victim of the } \\
\text { injustice." }\end{array}$ \\
\hline 3) & $\begin{array}{l}\text { Roa, M., and Klugman, B., } 2014 . \\
\text { Considering strategic litigation } \\
\text { as an advocacy tool: a case } \\
\text { study of the defence of } \\
\text { reproductive rights in } \\
\text { Colombia. Reproductive Health } \\
\text { Matters, 22(44), 31-41. }\end{array}$ & $\begin{array}{l}\text { "Traditionally, strategic litigation has been defined as } \\
\text { the litigation of a public interest case that will have a } \\
\text { broad impact on society beyond the specific interests of } \\
\text { the parties involved. In this approach, strategic } \\
\text { litigation serves as a powerful and innovative advocacy } \\
\text { tool by serving as a mechanism for government } \\
\text { accountability. National and international strategic } \\
\text { litigation can be used as an invaluable instrument by } \\
\text { the sexual and reproductive health and rights } \\
\text { movement on a global level to raise awareness of rights, } \\
\text { promote the need of vulnerable populations to have } \\
\text { access to those rights and demand government } \\
\text { compliance with human rights obligations." }\end{array}$ \\
\hline
\end{tabular}

\footnotetext{
${ }^{6}$ Google Scholar search of the term "strategic litigation" conducted on 27-01-2020 at Radboud University Nijmegen.
} 
4) Fuchs, G., 2013. Using strategic litigation for women's rights: Political restrictions in Poland and achievements of the women's movement. European Journal of Women's Studies, 20(1), 21-43.

5) Solvang, O., 2008. Chechnya and the European Court of Human Rights: The Merits of Strategic Litigation. Security and Human Rights, 19(3), 208219.

6) Barber, C., 2012. Tackling the evaluation challenge in human rights: assessing the impact of strategic litigation organisations. International Journal of Human Rights, 16(3), 411-435.

7) Riddell, T., and Morton, F.L., 2004. Government Use of Strategic Litigation: The Alberta Exported Gas Tax Reference. American Review of Canadian Studies, 34(3), 485509.

8) Aydın-Çakır, A., 2014. Judicialization of Politics by Elected Politicians: The Theory of Strategic Litigation. Political Research Quarterly, 67(3), 489503.

9) Fitzpatrick, B., 1992. Towards Strategic Litigation? Innovations in Sex Equality Litigation Procedures in the Member States of the European Community. International Journal of Comparative Labour Law and Industrial Relations, 8(3), 208-231.
"[Strategic litigation is] a strategy which uses the justice sector to achieve legal and social change by means of test cases."
"Strategic litigation projects (...) seek not only to win individual cases and provide redress to individual victims, but also to affect greater, lasting change by winning cases that have an impact beyond the case concerned."

"Non-profit organisations that undertake strategic human rights litigation (hereinafter referred to as strategic litigation organisations) use a combination of legal tools and traditional advocacy techniques to challenge human rights injustices and the impunity of those who perpetrate them. These organisations employ creative legal and non-legal strategies and use multiple forums to achieve their goals. Strategic litigation challenges individual and social injustices. With the goal of affecting positive legal, political and social change, strategic litigation's potential impact is much broader than traditional client-focused legal services."

"Strategic litigation is one method used by governments in their quest for political and constitutional advantage."

No definition is provided.

No definition is provided. Reference is made in the article to public interest litigation. 


\begin{tabular}{|c|c|c|}
\hline 10) & $\begin{array}{l}\text { Lewis, M.W., 2011. Potential } \\
\text { Pitfalls of Strategic Litigation: } \\
\text { How the Al-Aulaqi Lawsuit } \\
\text { Threatened to Undermine } \\
\text { International Humanitarian } \\
\text { Law. Loyola University } \\
\text { Chicago International Law } \\
\text { Review, 9(1), 177-186. }\end{array}$ & No definition is provided. \\
\hline 11) & $\begin{array}{l}\text { Vanhala, L., 2009. Anti- } \\
\text { discrimination policy actors } \\
\text { and their use of litigation } \\
\text { strategies: the influence of } \\
\text { identity politics. Journal of } \\
\text { European Public Policy, 16(5), } \\
\text { 738-754. }\end{array}$ & $\begin{array}{l}\text { "Litigation as a political strategy and courts as venues } \\
\text { to influence public policy." }\end{array}$ \\
\hline 12) & $\begin{array}{l}\text { Holzhacker, R., } 2009 . \\
\text { Transnational Strategies of } \\
\text { Civil Society Organizations } \\
\text { Striving for Equality and } \\
\text { Nondiscrimination: } \\
\text { Exchanging Information on } \\
\text { New EU Directives, Coalition } \\
\text { Strategies and Strategic } \\
\text { Litigation. In: L. Bruszt and R. } \\
\text { Holzhacker, eds. The } \\
\text { Transnationalization of } \\
\text { Economies, States, and Civil } \\
\text { Societies. New York: Springer, } \\
\text { 219-239. }\end{array}$ & $\begin{array}{l}\text { No clear definition is provided. Article refers to } \\
\text { litigation as a strategy. }\end{array}$ \\
\hline 13) & $\begin{array}{l}\text { Talbot, S., 2013. Advancing } \\
\text { human rights in patient care } \\
\text { through strategic litigation: } \\
\text { challenging medical } \\
\text { confidentiality issues in } \\
\text { countries in transition. Health } \\
\text { and Human Rights, 15(2), 69-79. }\end{array}$ & $\begin{array}{l}\text { "Strategic litigation refers primarily to the use of } \\
\text { litigation in a tactical manner, most notably in seeking } \\
\text { to address significant and/or systemic violations of } \\
\text { human rights. The aim is to produce an outcome that } \\
\text { goes beyond the individual claimant and case to } \\
\text { enhance human rights protection for other people } \\
\text { affected by similar human rights violations." }\end{array}$ \\
\hline 14) & $\begin{array}{l}\text { Lum, E.M., 2001. Hawai'i's } \\
\text { Response to Strategic } \\
\text { Litigation against Public } \\
\text { Participation and the } \\
\text { Protection of Citizens' Right to } \\
\text { Petition the Government. } \\
\text { University of Hawai'i Law } \\
\text { Review, 24(1), 411-440. }\end{array}$ & $\begin{array}{l}\text { The article is about SLAPPs: Strategic Lawsuit } \\
\text { Against Public Participation. The author of the } \\
\text { article replaces Lawsuit with Litigation, which } \\
\text { does not correspond to the original terminology, } \\
\text { made by prof. George W. Pring. }{ }^{7}\end{array}$ \\
\hline
\end{tabular}

\footnotetext{
7 See for example, Pring 1989.
} 
15) Fuchs, G., 2010. Promising

Paths to Pay Equity: A

Comparison of the Potentials

of Strategic Litigation,

Collective Bargaining and

Anti-Discrimination

Authorities in Switzerland,

Germany and France.

Available from

http://ssrn.com/abstract=166446

8.

16) Somaya, D., 2003. Strategic Determinants of Decisions not to Settle Patent Litigation.

Strategic Management Journal, 24, 17-38.

17) Anthony, T., 2009. Quantum of strategic litigation - quashing public participation. Australian Journal of Human Rights, 14(2), 1-38.

18) Sheldrick, B., 2014. Blocking Public Participation: the Use of Strategic Litigation to Silence Political Expression. Waterloo, ON: Wilfrid Laurier University Press.

19) Sileoni, S., 2011. The European Convention on Human Rights in the Italian System: From a Right Approach to a Strategic Litigation. Italian Journal of Public Law, 3(1), 65-125.

20) Gebara Fallah, D., 2019. Assessing Strategic Litigation Impact on Human Rights. Revista Direito e Práxis, 10(1), 759-765.
"In strategic litigation, which is a classic example of legal mobilization, test cases are brought to court in order to promote legal and social change. The aim may be to change law and policies; to ensure that laws are interpreted and enforced properly; or to identify gaps in the law. Jurisdiction may also directly alter practices or push the public and the political arenas for policy changes."

No clear definition is provided. Article is about strategic factors in litigation.

This article is about SLAPPs, similar to entry no. 14.

This book is about SLAPPs, similar to entries no. 14 and 17.

"[...] a strategic approach to the ECHR is arising, moving from litigations concerning individual claims to litigations that are able to challenge the political and social structure."

The article also speaks of using litigation to "change the legal and cultural status quo."

"[Strategic litigation is] what is in some systems called public interest litigation, test litigation, simply impact litigation, a growing area of practice globally that involves the increased use of the courts (national and supranational) by lawyers and civil society groups around the world, to advance human rights goals that go beyond the interests of just the applicants in the case. It reflects also the need to be strategic in the way litigation is done, to ensure that the process, both inside and outside of the courtroom, contributes to real success, beyond legal victory." 
Table of search engine HeinOnline ${ }^{8}$

Search Result

1) McEwen, G., 2011. Strategic

Litigation and Law Reform. Journal

of Animal Law, 7, 91-104.

2) Skelley, J., 2016. Open Source

Tactics: Bargaining Power for

Strategic Litigation. Chicago-Kent J. of Intellectual Property, 16(1), 1-35.

3) Carvalho S., and Baker, E., 2014. Strategic Litigation Experiences in the Inter-American Human Rights System. Sur - International Journal on Human Rights, 20, 449-460.

4) Serkin, S. 2016. Strategic Land Use Litigation: Pleading around Municipal Insurance. Boston College Environmental Affairs Law Review, 43(2), 463-484.

5) Winn, A., 2018. Chinese Workers vs. Walmart: Brainstorming Solutions to Funding Strategic Labor Litigation in the Wake of China's 2017 Foreign NGO Law. New York University Law Review, 93(6), 1854-1883.

6) Hatano, A., 2019. Can Strategic

Human Rights Litigation

Complement Social Movements: A Case Study of the Movement against Racism and Hate Speech in Japan. University of Pennsylvania Asian Law Review, 14(2), 228-274.

7) Gallagher, W.T., 2005. Strategic Intellectual Property Litigation, the Right of Publicity, and the Attenuation of Free Speech: Lessons from the Schwarzenegger Bobblehead Doll War (and Peace). Santa Clara Law Review, 45(3), 581616.
Definition of Strategic Litigation (if provided)

No definition is provided. Reference is made to public interest litigation.

No clear definition is provided. Article seems to refer more to tactics and strategies within litigation.

Several definitions from other sources are provided, not one is specifically chosen. A report from OSJI (see table organisations) is used, as well as a definition of public interest litigation, with which strategic litigation is equated in the article.

No clear definition is provided. The article is about strategic choices in litigation.
No definition is provided. Reference is made to public interest litigation.

\section{"Strategic human rights litigation is defined as the use of litigation to seek significant changes in legislation, policies, practices, or influencing public opinion and awareness to promote and protect human rights."}

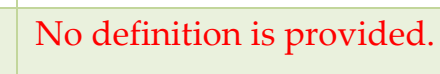

\footnotetext{
8 Search of the term "strategic litigation" conducted on 28-01-2020 at Radboud University Nijmegen. Search results without full text or written in a language other than English have been left out as well as search results that already came up in Google Scholar.
} 
8) Costello, M.A., 2014. Fulfilling the Unfulfilled Promise of Gideon: Litigation as a Viable Strategic Tool. Iowa Law Review, 99(5), 1951-1978.

9) LeDuc, A., 2018. Strategic Alliances as an Impact Litigation Model: Lessons from the Sepur Zarco Human Rights Case in Guatemala. Willamette Journal of International Law and Dispute Resolution, 25(2), 150-234.

10) Baluarte, D.C., 2012. Strategizing for Compliance: The Evolution of a Compliance Phase of Inter-American Court Litigation and the Strategic Imperative for Victims'

Representatives. American University International Law Review, 27(2), 263-320.

11) Gilson, R.J., 1990. The Devolution of the Legal Profession: A Demand Side Perspective. Maryland Law Review, 49, 869-916.

12) Meili, S., 2019. Constitutionalized Human Rights Law in Mexico: Hope for Central American Refugees. Harvard Human Rights Journal, 32, 103-146.

13) Case R.E. and Givens, T.E., 2010. ReEngineering Legal Opportunity Structures in the European Union: The Starting Line Group and the Politics of the Racial Equality Directive. Journal of Common Market Studies, 48(2), 221-242.

14) Abdikeeva A., et al, 2013. Assessing Legal Advocacy to Advance Roma Health in Macedonia, Romania, and Serbia. European Journal of Health Law, 20(5), 471-486.
No clear definition is provided. Article talks about litigation as strategy (see the title of the article).

"Strategic litigation, also known as impact litigation, uses the vehicle of litigation to protect the rights of classes of people, transform social norms, force political actors into affirmative action, and/or commit the community at large to incorporate a new narrative or truth in its underlying framework, often to prevent the same harms from happening again."

No clear definition is provided. The article talks about strategic choices in litigation.

"Litigation is strategic when pursued not to vindicate a substantive legal right, but as a device to secure a business advantage by imposing costs on the other party."

No definition is provided. Reference is made to cause lawyers.

No definition is provided.

No clear definition is provided. Strategic litigation is talked about as a tool of legal advocacy. 
15) Carrillo, A.J., and Yaksic, N.E., 2011. Re-Imaging the Human Rights Law Clinic. Maryland Journal of International Law, 26, 80-112.
"[Strategic human rights litigation] seeks to operate on the nexus between the judicial and political spheres, based on the constitutional recognition of rights and new procedural mechanisms for representing [social] interests. The purpose of raising judicially public conflicts or those that transcend the plane of the individual is to introduce issues into the agenda of social debate, [and] to question the process through which state public policies are defined, the content of such policies, as well as their implementation and potential social impact." This definition is taken from an NGO website.

16) Tushnet, M.V., 2004. Litigation

No definition is provided.

Campaigns and the Search for Constitutional Rules. Journal of Appellate Practice and Process, 6(1), 101-112.

17) TEI Comments on South African VAT Registration Requirements, 2014. Tax Executive, 66(3), 239-243.

No definition is provided.

18) Hartley, L., 2014. You Shall Not Pass: The Roma Travel Ban, Racial No definition is provided. Strategic Profiling in Macedonia, and Remedy under International Law. Penn State Law Review, 119(2), 583-606.

19) Henrard, K., and Gilbert, J., 2018. No definition is provided. Introducing Multidisciplinary Perspectives to the Adjudication of Indigenous Rights. Erasmus Law Review, 11(1), 1-5.

20) Ruibal, A., 2011. Book Review: The "A key development in all country studies, European Court of Human Rights and the Rights of Marginalised litigation is only mentioned in footnotes. Individuals and Minorities in National Context by D. Anagnostou and E. Psychogiopoulou (eds.). European Journal of Legal Studies, 4(1), 268-274. although with varied intensity, has been the use of strategic litigation by actors in civil society, who have increasingly approached the ECtHR not only as a venue to resolve particular cases, but also as a relevant instance in their pursuit of broader legal and policy change." 
Table of search engine Westlaw ${ }^{9}$

\begin{tabular}{|c|c|c|}
\hline \multicolumn{2}{|c|}{ Search Result } & \multirow{2}{*}{$\begin{array}{l}\text { Definition of Strategic Litigation (if } \\
\text { provided) } \\
\text { This search result is discussed extensively in } \\
\text { the article. }\end{array}$} \\
\hline 1) & $\begin{array}{l}\text { Ramsden, M. and Gledhill, K., } 2019 . \\
\text { Defining Strategic Litigation. Civil } \\
\text { Justice Quarterly, 4, 407-426. }\end{array}$ & \\
\hline 2) & $\begin{array}{l}\text { Botsford, P., 2014. The Noble } \\
\text { Pursuit of Litigation. International } \\
\text { Bar Association Global Insight, } \\
68(2), 44-48 .\end{array}$ & $\begin{array}{l}\text { "how test case litigation is pursued as a } \\
\text { deliberate strategy to effect systemic change, } \\
\text { hence the development of the term 'strategic } \\
\text { litigation'. This use of public interest litigation as } \\
\text { part of a wider campaigning agenda has } \\
\text { increased over the past decade or so both in the } \\
\text { UK and internationally in line with an increased } \\
\text { interest in human rights." } \\
\text { "A strategic case is pursued in order to achieve } \\
\text { some degree of law reform beyond the specific } \\
\text { case being brought. This may be by enforcing } \\
\text { laws already in place, clarifying laws that are } \\
\text { untested, challenging the way that laws are } \\
\text { enforced (such as the D.H. and Others v Czech } \\
\text { Republic case), or even ensuring a law is not } \\
\text { enforced (...). } \\
\text { It also raises awareness of the issue in question as } \\
\text { the court proceedings often bring press } \\
\text { coverage." }\end{array}$ \\
\hline 3) & $\begin{array}{l}\text { Kenna, P., 2017. Social Inclusion and } \\
\text { the Legal System - Public Interest } \\
\text { Law in Ireland. Irish Jurist, 57, 225- } \\
227 .\end{array}$ & $\begin{array}{l}\text { No definition is provided. Reference is made } \\
\text { to public interest litigation. }\end{array}$ \\
\hline 4) & $\begin{array}{l}\text { Zingales, N., 2019. Book review: } \\
\text { Courts, Privacy and Data Protection } \\
\text { in the Digital Environment, by M. } \\
\text { Brkan and E. Psychogiopoulou } \\
\text { (eds). European Law Review, 44(3), } \\
\text { 435-436. }\end{array}$ & $\begin{array}{l}\text { "Litigation that is primarily concerned with law } \\
\text { and policy reform, based on the selection of cases } \\
\text { that allow litigants to penetrate deeper into and } \\
\text { address wider societal problems." }\end{array}$ \\
\hline 5) & $\begin{array}{l}\text { Lewis, O., 2011. Advancing legal } \\
\text { capacity jurisprudence. European } \\
\text { Human Rights Law Review, 6, 700- } \\
714 .\end{array}$ & $\begin{array}{l}\text { "Strategic litigation enables progressive } \\
\text { jurisprudence by encouraging a positive outcome } \\
\text { in a particular case." } \\
\text { (strategic) litigation is called an advocacy } \\
\text { tool. }\end{array}$ \\
\hline
\end{tabular}

\footnotetext{
9 Search of the term "strategic litigation" conducted on 28-01-2020 at Radboud University Nijmegen. Only search results under the heading "journals" were included. Search results without full text or written in a language other than English have been left out as well as search results that already came up in Google Scholar/HeinOnline.
} 
6) Mahomed, F., Lord, J.E., and Ashley Stei, M., 2019. Transposing the Convention on the Rights of Persons with Disabilities in Africa: the role of disabled peoples' organisations. African Journal of International and Comparative Law, 27(3), 335-358.

7) Lewis, O., 2017. Disabling legal Review, 1, 49-58.

8) Dawson, M., 2013. Re-generating Europe through Human Rights? Proceduralism in European Human Rights Law. German Law Journal, 14(5), 651-671.
Strategic litigation and strategic advocacy are mentioned as tools to advance human rights protection for disabled people. barriers. European Human Rights Law

"The Shtukaturov case is an example of strategic litigation (or impact or test-case litigation), a method that seeks not only a win for the individual client, but also a change in the position of others: the court obviously, and often the government and civil society groups as well. At a minimum, strategic litigation has a documentation role as judicial findings are seen as balanced, unbiased and carry more weight than reports of NGOs or national human rights institutions."

"The founding premise of this literature is that Courts have become forums for political mobilization by organized groups who seek to use legal opportunities to fulfill collective and political claims. This will often involve the selection and support of promising litigants in national jurisdictions. By bringing test cases, these litigants may encourage the resolution of rights claims before higher international Courts. The advantage of such a strategy is considerable: While a ruling by a lower Court may only provide relief to the affected individual, higher Court rulings, including from the ECJ, may carry effects across a wide jurisdiction."

No definition is provided.

9) Sileoni, S., 2010. Italy's treatment of immigrants and the European Convention on Human Rights. Journal of Immigration Asylum and Nationality Law, 24(2), 159-172.

10) Gilbert, J., 2017. Litigation indigenous peoples' rights in Africa: potentials, challenges and limitations. International $\mathcal{E}$ Comparative Law Quarterly, 66(3), 657-686.

11) Dawson, M., Muir, E., and Claes, M., 2012. Enforcing the EU's Right "litigation designed to advance the common good." "litigation is part of a strategy for social change."

Revolution: the Case of Equality. European Human Rights Law Review, 3, 276-291. 
12) Nolan, A., 2015. Not fit for purpose?

No definition is provided.

Human rights in times of financial and economic crisis. European Human Rights Law Review, 4, 360-371.

13) Harker, M., Hviid, M., and Wright, K., 2011. The EU rules on standing in merger cases: should firms have to demonstrate "harm to competition"? European Law Review, 36(4), 500-523.

14) Psychogiopoulou, E., 2012. Copyright enforcement, human rights protection and the responsibilities of internet service providers after Scarlet. European Intellectual Property Review, 34(8), 552-555.

15) McAllister, D.M., 2002. The Attorney General's Role as Guardian of the

No definition is provided. Reference is made to public interest litigation.

Public Interest in Charter Litigation.

Windsor Yearbook of Access to Justice, 21, 47-90.

16) Pilliar, A., 2015. Exploring a Law Firm No definition is provided. Business Model to Improve Access to Justice. Windsor Yearbook of Access to Justice, 32, 1-23.

17) Chapter III Activities of No definition is provided. Rapporteurships, Country and Thematic Reports, and Promotion, 2017. Annual Report of the InterAmerican Commission on Human Rights.

18) McAdam, J., 2016. Building No definition is provided. Reference is International Approaches to Climate made to test cases. Change, Disasters, and Displacement. Windsor Yearbook of Access to Justice, 33, 1-14.

19) Gerards, J., 2012. The prism of fundamental rights. European

No definition is provided. Constitutional Law Review, 8(2), 173202.

20) Neil Campbell A., and William Rowley QC, J., 2011. Proposals for Evolving the No definition is provided. Patchwork of Domestic Monopolisation and Dominance Law. Business Law International, 12(1), 5-70. 